\title{
A Comparison of Lexical Feedback on Writing Received from Peers and a Teacher
}

\author{
Rachael Ruegg \\ Akita International University \\ doi: http://dx.doi.org/10.7820/vli.v02.1.ruegg
}

\begin{abstract}
While a vast number of studies have compared feedback from different sources, few studies if any have compared feedback on lexis from different sources. It is therefore unclear whether the amount or type of feedback given by peers is comparable to that given by a teacher. This study considers feedback on lexical errors in writing as a method of incidental vocabulary instruction and compares lexical feedback given by peers and a teacher over a period of one academic year. While it was found that the teacher gave significantly more feedback on word choice than the peers did, there was no significant difference between the amount of feedback on word use, or the total amount of lexical feedback given by peers and the teacher. It was also found that both peers and the teacher gave a considerable amount of feedback on word use and much less on word choice. If written feedback on writing is to be effective as a form of incidental vocabulary instruction, it is suggested that both teachers and peers should focus more on word choice when giving feedback on writing.
\end{abstract}

\section{Introduction}

The current study compares lexical feedback on writing received from peers and a teacher over a period of one academic year. While a vast number of studies have compared feedback from different sources, few studies if any have compared feedback on lexis from different sources. It is therefore unclear whether the amount or type of feedback given by peers is comparable to that given by a teacher. The following research question will be addressed: How does the quantity of lexical feedback received from peers and from the teacher differ?

\section{Background}

In many curricula, vocabulary learning is considered to be the mandate of reading courses (e.g. Collins, 2001; Kirkgoz, 2006; Kirschner \& Wexler, 2002), while the improvement of grammatical ability is associated with writing courses (e.g. Beckett, Gonzalez, \& Schwartz, 2004; Chimbganda, 2000; Ferris \& Hedgcock, 2004). However, it has been found that reading can be facilitative of grammar knowledge (Krashen, 1982; Trahey \& White, 1993). Likewise, it has also been found that learners are able to improve their lexical performance through practices employed during writing instruction (Ferris, 2003; Ferris \& Roberts, 2001). Indeed, Swain (1995) argues that pushed output is required for acquisition because when learners produce output they need to pay attention to language, whereas when they 
process input attention only needs to be paid to the meaning. Moreover, Ellis and He (1999) found that modified output was more effective than modified input for incidental vocabulary learning and concluded that "Producing new words helps learners process them more deeply, whether for comprehension or for acquisition, than simply hearing (or reading) them". (p. 297). As this paper will do, both Raimes (1985) and Santos (1988) have also appealed for more focus on vocabulary in writing courses.

Nation (2001) states that "Teachers can have a direct influence on noticing in speaking and writing tasks by giving thought to ...the written input..." (p. 66). However, in order to maximise learner motivation it is often suggested that learners be given freedom to choose their own topics (Benson, 2001; Freeman \& Freeman, 1989; Hudelson, 1989; Johnson, 1989; Little, 1991; Sayers, 1989; Walker, 2003). This is especially the case at the university level where learners may be learning to write in order to prepare for a future course of study in their chosen field. Indeed, Laufer and Hulstijn (2001) found that in these conditions need was high, search was moderate and evaluation was high. Of all the language-learning activities compared in their paper, writing about a self-selected topic resulted in the most favourable conditions for vocabulary retention.

If teachers are unable to control the input encountered by students, then providing feedback on output could be the most effective means of facilitating vocabulary learning. In reviewing the literature on error correction, Truscott (2007) found that studies that included correction of all error types tended to result in significant effects, whereas studies that focused specifically on grammatical errors, tended to result in insignificant effects. Specifically, studies that included spelling errors appear to have found positive effects for error correction. This offers promise for feedback on vocabulary as a method of facilitating vocabulary instruction.

Many studies have compared feedback from peers with that from teachers. Most of that research seems to have found that peer feedback is comparable to teacher feedback in terms of its effect on writing (Caulk, 1994; Donato, 1994), while Hedgcock and Lefkowitz (1992) and Paulus (1999) found that the final drafts of essays which had been subject to peer feedback received higher scores than those which had been subject to teacher feedback. Peer feedback has also been found to have a positive effect on learners' confidence (Gungle \& Taylor, 1989; Mittan, 1989; Tsui \& Ng, 2000; Zhang, 1995). However, it has been stated that peers focus on different aspects of writing than teachers do (Connor \& Asenavage, 1994; Hedgcock \& Lefkowitz, 1992; Yang, Badger \& Yu, 2006). Very little research has been conducted into lexical feedback on writing and it is unclear to what extent peers and teachers focus on lexical issues when providing feedback on writing.

This study considers feedback on lexical errors in writing as a method of incidental vocabulary instruction. It compares lexical feedback given by peers and by a teacher over a period of one academic year.

\section{Method and results}

The participants in the current study were 51 second-year students in the department of English at a private foreign language university in central Japan. The 
students were in four intact classes, all of which were in the bottom ability stream at the university. Students were assigned to ability streams on the basis of scores from the reading and listening sections of TOEFL Institutional Testing Program (ITP) as well as in-house speaking and writing tests. Within the bottom ability stream, students had been randomly placed into one of five classes. Therefore, the overall ability level of each of the four intact classes can be considered to be equal. Two of the classes constituted the peer feedback group, while the other two constituted the teacher feedback group.

Over the course of the academic year the students wrote eight essays, for each of which they were asked to write and submit three drafts; two preliminary drafts and a final draft, totaling 16 preliminary drafts per student over the one-year period. Students in the peer feedback group gave and received peer feedback alone on all preliminary drafts over the academic year, while those in the teacher feedback group received teacher feedback exclusively on all preliminary drafts for the same period. All final drafts were read and graded by the teacher, but no feedback was provided on the final drafts apart from the grades. All the preliminary drafts written by these students over the period of one academic year were analysed in terms of the types and amount of lexical feedback they received.

For the purpose of this study, lexical feedback was defined in the same way as Ferris (2003) defined "Word choice errors". These included word choice and word use. The lexical feedback was divided into two aspects (word choice and word use) of lexical knowledge in order to ascertain whether there was a significant difference in the quantity of feedback of these different types. A checklist was used by both the peers and the teacher when they provided feedback. The questions on the checklist that were determined to constitute lexical feedback and the aspect of lexis they were determined to relate to can be seen in Figure 1.

\begin{tabular}{ll}
\hline \multicolumn{1}{c}{ Question } & Aspect \\
\hline $\begin{array}{l}\text { Please suggest more sophisticated vocabulary. } \\
\text { Is each word used in the correct context? }\end{array}$ & Word choice \\
\hline Is each word used correctly? & Word use \\
$\begin{array}{l}\text { Is the correct form of each word used? } \\
\text { Is each word spelt correctly? }\end{array}$ \\
\hline
\end{tabular}

Figure 1. Questions related to lexis on the feedback checklists.

The descriptive statistics for the number of instances of feedback each learner in the peer feedback group received over the one-year period can be seen in Table 1.

The descriptive statistics for the number of instances of feedback each learner in the teacher feedback group received over the one-year period can be seen in Table 2. 
Table 1. Instances of Peer Feedback $(n=23)$

\begin{tabular}{lcrrr}
\hline Feedback & Minimum & Maximum & Mean & \multicolumn{1}{c}{ SD } \\
\hline Word choice & 0 & 7 & 1.19 & 2.131 \\
Word use & 0 & 139 & 18.67 & 34.735 \\
Total & 0 & 139 & 19.85 & 35.003 \\
\hline
\end{tabular}

Table 2. Instances of Teacher Feedback $(n=28)$

\begin{tabular}{lccrr}
\hline Feedback & Minimum & Maximum & Mean & \multicolumn{1}{c}{ SD } \\
\hline Word choice & 0 & 16 & 3.61 & 4.562 \\
Word use & 0 & 88 & 20.42 & 24.510 \\
Total & 0 & 89 & 24.03 & 25.313 \\
\hline
\end{tabular}

One-way ANOVA (2-tailed) was used to measure difference between the amount of feedback on word choice, word use and the total amount of lexical feedback given by peers and by the teacher.

The results of the one-way ANOVA showed that there was no significant difference in terms of the amount of feedback on word use $(p=0.815)$ or total feedback $(p=0.584)$. On the other hand, the difference between the amount of feedback on word choice in the two groups $[F(1,61)=6.542, p=0.013]$ was found to be significant at the 0.05 level.

\section{Discussion and conclusions}

It can be seen that both peers and the teacher gave a considerable amount of feedback on word use and much less on word choice. In fact, the maximum number of comments any student received related to word choice over the entire academic year was only 16 which is equivalent to one comment on each preliminary draft. While there was no difference between the amount of feedback given on word use or total feedback given, the teacher gave significantly more feedback on word choice than the peer reviewers did.

Although the teacher gave significantly more feedback on word choice than the peers did, even the amount given by the teacher (which amounted to a maximum of 16 feedback points over the semester) would appear to be insufficient. If written feedback on writing is to be effective as a form of incidental vocabulary instruction, it is suggested that teachers should focus more on word choice when giving feedback on writing.

Hyland (2003) states that while teacher feedback can only be seen to improve writing skills, peer feedback can improve learners' skills doubly: Firstly in the process of critiquing a peer's writing and secondly in the process of receiving feedback from the peer. Training students to focus on word choice to a greater extent when they take part in peer review may therefore have two possible benefits: it may increase their attention to word choice in their own writing and also during the peer review process itself students are likely to search (in their dictionary for 
unknown words) and evaluate (possible alternative words to suggest to their peer). According to Laufer and Hulstijn (2001) such activities are likely to result in vocabulary retention.

It appears that peer reviewers are able to give as much feedback on word use as teachers. In future research, it would be worthwhile to evaluate the accuracy of such feedback given by peers and by the teacher.

This study only investigated the feedback given by one teacher. Therefore, if this study was reproduced different results may be found. In future research it would be useful to analyse feedback from a number of different teachers who use the same feedback checklist to find out how much teachers vary in the amount of lexical feedback they give their students.

\section{References}

Beckett, G., Gonzalez, V., \& Schwartz, H. (2004). Content-based ESL writing curriculum: A language socialization model. NABE Journal of Research and Practice, 2 (1), 161-175.

Benson, P. (2001). Teaching and researching autonomy in language learning. Harlow: Pearson Education.

Caulk, N. (1994). Comparing teacher and student responses to written work. TESOL Quarterly, 28, 181-188. doi:10.2307/3587209

Chimbganda, A. (2000). Communication strategies used in the writing of answers in biology by ESL first-year science students of the University of Botswana. English for Specific Purposes, 19, 305-329. doi:10.1016/S0889-4906(99)00002-2

Collins, M. (2001). The multi-cultural classroom: Immigrants reading the literature of the immigrant experience. MinneTESOL/WITESOL Journal, 18, 13-22.

Connor, U., \& Asenavage, K. (1994). Peer response groups in ESL writing classes: How much impact on revision? Journal of Second Language Writing, 3, 257276. doi:10.1016/1060-3743(94)90019-1

Donato, R. (1994). Collective scaffolding in second language learning. In J. Lantolf \& G. Appel (Eds.), Vygotskian approaches to second language research (pp. 33-56). Westport: Ablex Publishing.

Ellis, R., \& He, X. (1999). The roles of modified input and output in the incidental acquisition of word meanings. Studies in Second Language Acquisition, 21 (2), 297-301.

Ferris, D. (2003). Response to student writing: Implications for second language students. Mahwah, NJ: Lawrence Erlbaum Associates.

Ferris, D., \& Hedgcock, J. (2004). Teaching ESL composition: Purpose, process and practice. Mahwah, NJ: Lawrence Erlbaum Associates.

Ferris, D.R., \& Roberts, B. (2001). Error feedback in L2 writing classes. How explicit does it need to be? Journal of Second Language Writing, 10, 161-184. doi:10.1016/S1060-3743(01)00039-X 
Freeman, Y., \& Freeman, D. (1989). Whole language approaches to writing with secondary students of English as a second language. In D. Johnson \& D. Roen (Eds.), Richness in writing (pp. 177-192). New York, NY: Longman.

Gungle, B., \& Taylor, V. (1989). Writing apprehension and second language writers. In D. Johnson \& D. Roen (Eds.), Richness in writing: Empowering ESL students (pp. 235-248). New York, NY: Longman.

Hedgcock, J., \& Lefkowitz, N. (1992). Collective oral/aural revision in foreign language writing instruction. Journal of Second Language Writing, 1 (3), 255276. doi:10.1016/1060-3743(92)90006-B

Hudelson, S. (1989). A tale of two children: Individual differences in ESL children's writing. In D. Johnson \& D. Roen (Eds.), Richness in writing (pp. 84-99). New York, NY: Longman.

Hyland, K. (2003). Second language writing. Cambridge: Cambridge University Press.

Johnson, D. (1989). Enriching task contexts for second language writing: Power through interpersonal roles. In D. Johnson \& D. Roen (Eds.), Richness in writing (pp. 39-54). New York, NY: Longman.

Kirkgoz, Y. (2006). Designing a corpus based reading course for academic purposes. The Reading Matrix, 6 (3), 281-298. Retrieved from http://www. readingmatrix.com/articles/kirkgoz/article.pdf

Kirschner, M., \& Wexler, C. (2002). Caravaggio: A design for an interdisciplinary content-based EAP/ESP unit. Journal of English for Academic Purposes, 1 (2), 163-183. doi:10.1016/S1475-1585(02)00014-0

Krashen, S. (1982). Principles and practice in second language acquisition. Oxford: Pergamon.

Laufer, B., \& Hulstijn, J. (2001). Incidental vocabulary acquisition in a second language: The construct of task-induced involvement. Applied Linguistics, 22 (1), 1-26.

Little, D. (1991). Learner autonomy: Definitions, issues and problems. Dublin: Authentik.

Mittan, R. (1989). The peer review process: Harnessing students' communicative power. In D. Johnson \& D. Roen (Eds.), Richness in writing: Empowering ESL students (pp. 207-219). New York, NY: Longman.

Nation, I.S.P. (2001). Learning vocabulary in another language. Cambridge: Cambridge University Press.

Paulus, T. (1999). The effect of peer and teacher feedback on student writing. Journal of Second Language Writing, 8, 265-289. doi:10.1016/S1060-3743(99) 80117-9

Raimes, A. (1985). What unskilled writers do as they write: A classroom study of composing. TESOL Quarterly, 19, 229-258. doi:10.2307/3586828

Santos, T. (1988). Professors' reactions to the academic writing of nonnativespeaking students. TESOL Quarterly, 22 (1), 69-88. doi:10.2307/3587062 
Sayers, D. (1989). Bilingual sister classes in computer writing networks. In D. Johnson \& D. Roen (Eds.), Richness in writing (pp. 120-133). New York, NY: Longman.

Swain, M. (1995). Three functions of output in second language learning. In Cook, G. \& Seidhofer, B. (Eds.). Principles and practices in the study of language (pp. 125-144). Oxford: Oxford University Press.

Trahey, M., \& White, L. (1993). Positive evidence and preemption in the second language classroom. Studies in Second Language Acquisition, 15 (2), 181-204. doi:10.1017/S0272263100011955

Trustcott, J. (2007). The effect of error correction of learners' ability to write accurately. Journal of Second Language Writing, 16, 255-272. doi:10.1016/j. jslw.2007.06.003

Tsui, A., \& Ng, M. (2000). Do secondary L2 writers benefit from peer comments? Journal of Second Language Writing, 9, 147-170. doi:10.1016/S1060-3743(00) 00022-9

Walker, B. (2003). The cultivation of student self-efficacy in reading and writing. Reading and Writing Quarterly, 19, 173-187. doi:10.1080/10573560308217

Yang, M., Badger, R., \& Yu, Z. (2006). A comparative study of peer and teacher feedback in a Chinese EFL writing class. Journal of Second Language Writing, 15, 179-200. doi:10.1016/j.jslw.2006.09.004

Zhang, S. (1995). Reexamining the affective advantage of peer feedback in the ESL writing class. Journal of Second Language Writing, 4 (3), 209-222. doi:10. 1016/1060-3743(95)90010-1 